\title{
Investigating rare and ultrarare epilepsy syndromes with Drosophila models
}

\author{
Paul Lasko ${ }^{1,2^{*}} \quad$ Kevin Lüthy ${ }^{1,3^{*}}$ \\ ${ }^{1}$ Department of Human Genetics, Radboud University Medical Centre, Nijmegen, Netherlands \\ ${ }^{2}$ Department of Biology, McGill University, Montréal, Québec, Canada \\ ${ }^{3}$ Donders Institute for Brain, Cognition and Behaviour, Radboud University Medical Centre, Nijmegen, Netherlands
}

\begin{abstract}
One in three epilepsy cases is drug resistant, and seizures often begin in infancy, when they are life-threatening and when therapeutic options are highly limited. An important tool for prioritizing and validating genes associated with epileptic conditions, which is suitable for large-scale screening, is disease modeling in Drosophila. Approximately two-thirds of disease genes are conserved in Drosophila, and gene-specific fly models exhibit behavioral changes that are related to symptoms of epilepsy. Models are based on behavior readouts, seizure-like attacks and paralysis following stimulation, and neuronal, cell-biological readouts that are in the majority based on changes in nerve cell activity or morphology. In this review, we focus on behavioral phenotypes. Importantly, Drosophila modeling is independent of, and complementary to, other approaches that are computational and based on systems analysis. The large number of known epilepsy-associated gene variants indicates a need for efficient research strategies. We will discuss the status quo of epilepsy disease modelling in Drosophila and describe promising steps towards the development of new drugs to reduce seizure rates and alleviate other epileptic symptoms.
\end{abstract}

\section{Keywords}

Neurological disorders, Epilepsy, Drosophila, Neurogenetics, Disease model

\section{Peer Review}

The peer reviewers who approve this article are:

1. Richard A Baines, Division of Neuroscience and Experimental Psychology, School of Biological Sciences, Faculty of Biology, Medicine and Health, University of Manchester, Manchester Academic Health Science Centre, Manchester, UK Competing interests: No competing interests were disclosed.

2. Daniela Zarnescu, Department of Molecular and Cellular Biology, University of Arizona, Arizona, USA Competing interests: Daniela Zarnescu serves as scientific advisor for Fox Chase Chemical Diversity Center Inc. 
*Corresponding author: Paul Lasko (paul.lasko@megill.ca); Kevin Lüthy (kevin.luthy@radboudumc.nl)

Competing interests: The authors declare that they have no competing interests.

Grant information: K. L. and P. L. were both supported by the Excellence Initiative of Radboud University.

The funders had no role in study design, data collection and analysis, decision to publish, or preparation of the manuscript.

Copyright: (c) 2021 Lasko P et al. This is an open access article distributed under the terms of the Creative Commons Attribution License, which permits unrestricted use, distribution, and reproductison in any medium, provided the original work is properly cited.

How to cite this article: Lasko P and Lüthy K. Investigating rare and ultrarare epilepsy syndromes with Drosophila models. Faculty Reviews 2021 10:(10) https://doi.org/10.12703/r/10-10

Published: 29 Jan 2021, Faculty Reviews 10:(10) https://doi.org/10.12703/r/10-10 


\section{Introduction}

\section{Diversity of epilepsy genetics}

Epilepsy has a strong hereditary component; over the past decade, more than 100 causative epilepsy genes have been discovered by worldwide epilepsy screening consortia ${ }^{1,2}$. Approximately $50 \%$ of cases can be traced to single genetic mutations $^{2-4}$. The identification of these genes by worldwide consortia is an important step toward the development of new therapeutic approaches because modeling the disease conditions requires a powerful genetic approach. Given the rapid progress in stem cell technology, patient-derived models are one attractive avenue of investigation ${ }^{5}$. However, the heterogeneity of human genomes poses challenges, as differences in genetic background can alter the phenotype produced by a given mutation. These challenges can be partially overcome in the Drosophila model through crossings to achieve isogenized lines, as well as the standardization of transgenic insertions to reach a stable genetic background $^{6-9}$. However, genetic drift remains a concern when transgenic lines are kept over many generations and can lead to differing results from different labs that ostensibly use the same stocks.

Anti-seizure drugs (ASDs) aim to control epileptic symptoms and improve quality of life in epilepsy patients. Despite very good results for two-thirds of those affected, seizures remain refractory, or drug-resistant, in one-third of patients ${ }^{10}$. Even increased dosage or combination therapy has not produced a significant reduction in the fraction of intractable cases. In addition, epilepsy patients can develop further comorbidities despite seizure suppression, including intellectual disability (ID) and autism spectrum disorder ${ }^{11,12}$.

\section{Artificial intelligence-based detection of epilepsy- associated phenotypes}

To what extent can behavior testing be automated in data analysis? Several readouts have been developed, including the tracking of fly movements by video analysis to capture either momentary adult fly seizure-like behavior or long-term movement and activity patterns ${ }^{13-15}$. Readouts of larval motor coordination have also been employed in seizure-associated studies ${ }^{16}$. An intriguing alternative to screens searching for genetic modifiers is the Janelia Fly Olympiad project. In this project, 2,205 specific anatomical regions were acutely silenced using $s h i^{t s}$ or overexcited using $\operatorname{TrpAl}$ in order to track behavior changes automatically utilizing computer vision algorithms ${ }^{17,18}$. This technical approach registered a broad range of behavior patterns, including locomotion, coordination, and climbing that together reflect epilepsy-associated paradigms ${ }^{19}$. Righting behavior and side-steps, for instance, have been previously employed to quantify epilepsy-associated phenotypes ${ }^{20,21}$. The combination of increasingly efficient behavior readouts and genetic screening libraries enabling the regulation of nearly all genes with tissue-specific promotors holds great promise for future screens, in which the advantages and limitations of the chosen readout (Figure 1) will determine the successful identification of disease-relevant phenotypes. This promises to extend our knowledge beyond the identification of single genes toward learning about how they interact to produce disease states.

\section{Disease modeling in Drosophila and screens for conserved, disease-associated factors}

The fruit fly Drosophila melanogaster has contributed a great deal to genetic research, and around $70 \%$ of the fly's genes
Mechanical
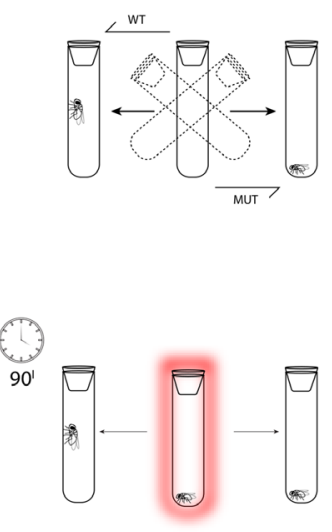

Temperature
Electrical
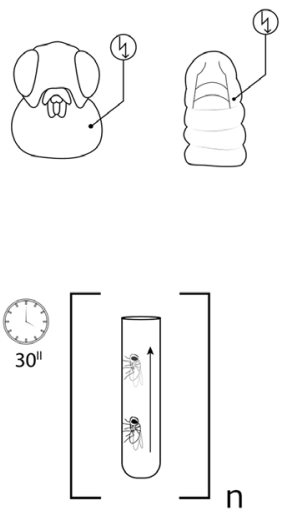

Geotaxis

\section{Circadian}
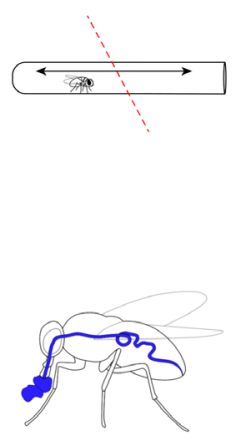

Pharmacological

Figure 1. Epilepsy models utilizing Drosophila behavior. Stimulation of Drosophila can induce seizure-like behavior in susceptible animals. Quantification typically reflects the recovery after stimulation, the frequency and duration of seizuring effects, or significant behavioral changes. Circadian rhythm (sleep/wake) and geotaxis assays measure the behavior of flies in a test chamber to reveal susceptibility to either seizure-like or complex behavior changes associated with epileptic pathology. The paradigms can be combined with typically oral uptake of pharmacological compounds to induce or suppress these phenotypes. MUT, mutant; WT, wild type. 
have orthologs in humans ${ }^{22}$. Through experiments ranging from ethological to molecular biological assays, key insights have been gained from Drosophila into the genetic basis of hereditary disorders, including Alzheimer's disease and epilepsy. Forward genetic screens in Drosophila have identified factors affecting general functions such as sleep $^{23}$ as well as many that associate with ID and autism spectrum disorder ${ }^{24}$. With respect to epilepsy, geneticists and clinicians have identified causative variants in more than 100 genes, the majority of which have conserved orthologs in Drosophila, enabling fast and inexpensive modeling of human patients' conditions ${ }^{25,26}$. Even the intricate role of glial cell contribution to hereditary epilepsies has been investigated through interactions that have been conserved on the level of both molecular and cellular interactions ${ }^{27,28}$. The important contribution of Drosophila to epilepsy research is reflected in a Google Scholar search for <'Drosophila' AND 'epilepsy'> that yields 28,200 publications, including around 12,000 from the past 5 years, as well as 700 related patents.

Here, we outline the current state of epilepsy modeling in Drosophila and indicate methodological innovations that enable new approaches to disease modeling, such as CRISPR-Cas9 genetic screens.

\section{Epilepsy modeling in Drosophila} Behavior experiments

Drosophila has been used to model epilepsy for nearly 50 years, since the discovery of bang-sensitive alleles ${ }^{29}$. These genetic mutations cause the animals to respond to a mechanical or temperature stress with a characteristic, seizure-like response. Three criteria for epilepsy model readouts have been established, namely quantifiable seizure susceptibility thresholds, a baseline genetic control, and resemblance to human seizuring ${ }^{30}$.

The fly model helped to determine that seizure-like behavior can be evoked by global central nervous system activity that, at least for the characteristic muscle tremors, requires long-range interactions in the nervous system rather than regionally compartmentalized foci of activity ${ }^{21}$. While global brain excitation is sufficient to induce an attack, in classic bang-sensitive alleles only the involvement of certain brain regions was necessary in order to elicit bang sensitivity or temperature sensitivity. These epilepsy paradigms required the genetic targeting of different, yet overlapping, brain regions in order to initiate the respective seizure-like effects, providing an insight into the complexity of invertebrate analogous behavior to epileptic seizuring (Table 1).

Next, we elaborate on these respective assay types and summarize behavioral and physiological assays most relevant to epilepsy-associated behavior (Figure 1) in the context of representative studies.

Mechanical stimulus. The discovery of mutations in genes coding for sodium and potassium channels led to mechanistic insights into neuronal excitability, e.g. Drosophila mutants with corresponding human orthologs paralytic/SCN1A, slowpokel KCNMA1, and seizure/KCNH2/KCNH7 ${ }^{31}$. In parallel, the orthologous human epilepsy variants were found to occur with high prevalence in patients ${ }^{32}$. It is important to stress that bang sensitivity describes a specific, seizure-like animal behavior pattern as opposed to general loss of activity. This behavior pattern begins once a threshold has been reached and occurs in an all-or-nothing manner through a periodic sequence of shaking and loss of coordination. The inactive phase has been found to be disrupted by a tap to the experimental chamber, indicating that the internal state of the central nervous system in seizure-like attacks is directly affected by external stimuli.

Mechanical induction of seizure-like states has identified alleles in more than 50 genes, again including orthologs of causative disease genes ${ }^{21,29,33}$. In some cases, epilepsy-related phenotypes were revealed through refined genetic strategies since full knockout alleles can result in adult-lethal animals ${ }^{34-36}$.

A functionally related group of gap junction genes has been identified owing to the characteristic induced shaking, beginning with shaking $B(\operatorname{shakB})$ and its interaction with ogre/Innexin1, but also stress-sensitive $B(\operatorname{ses} B)^{37-39}$. Despite substantial divergence in these genes between human and Drosophila, their role in human seizure progression and in blocking seizures means

Table 1. Well-characterized seizure-associated genes in Drosophila.

\begin{tabular}{|c|c|c|c|c|c|c|}
\hline Gene name & Homolog & Bang & Heat & Unc. & Function & Reference \\
\hline Paralytic (para) & SCN1A & + & + & + & $\mathrm{Na}^{+}$channel $\alpha$ subunit & Parker et al., $2011^{31}$ \\
\hline slowpoke (slo) & KCNMA1 & - & + & - & $\mathrm{K}^{+}$channel subunit & Moss et al., $1996^{40}$ \\
\hline seizure (sei) & $\mathrm{KCNH} 2 / 7$ & + & + & + & $\mathrm{K}^{+}$channel subunit & $\begin{array}{l}\text { Titus et al., } 1997^{41} \\
\text { Wang et al., } 1997^{42}\end{array}$ \\
\hline easily shocked (eas) & ETNK1 & + & - & - & Ethanolamine kinase & Pavlidis et al., $1994^{43}$ \\
\hline Shaker (Sh) & KCNA1 & - & - & + & $\mathrm{K}^{+}$channel $\alpha$ subunit & Salkoff \& Wyman, $1981^{44}$ \\
\hline mustard (mtd) & OXR1 & + & - & - & Oxidative stress sensor & Wang et al., $2019^{45}$ \\
\hline shaker B (shakB) & - & - & + & + & Gap junction subunit & Crompton et al., $1995^{37}$ \\
\hline
\end{tabular}

The closest human ortholog and experimental results for bang sensitivity, heat sensitivity, and uncoordinated behavior are listed. The bang sensitivity negative mutant flies displayed neurophysiological or motor defects prior to stimulation. 
that the insights from the Drosophila model nevertheless hold translational value ${ }^{46}$.

A further 155 genes are tagged as uncoordinated and 42 more are linked to further epilepsy-relevant readouts in the FlyBase Human Disease Model Report (flybase.org/lists/FBhh, Table 1). These represent an understudied set of potential epilepsy models.

Temperature elevation. Mutations in 1,200 Drosophila genes have been registered as associated with heat sensitivity. Increasing the temperature of ectothermal animals increases the temperature of the central nervous system and induces the stereotypic seizure response in sensitized genetic models ${ }^{21,33-35,47}$. Surprisingly few $(\sim 30 \%)$ of the genes that can mutate to produce mechanically induced phenotypes co-occur with those that are temperature dependent. This is consistent with findings in the paralytic (para) mutant para ${ }^{b s s}$, which demonstrated that, in spite of effects on global brain activity underlying responses to mechanical or thermal stress, the effects are linked to distinct brain regions ${ }^{21}$. While a strong focus in behavioral experiments has been placed on activity bursts resembling seizures, other approaches attempt to capture paroxysmal epileptic dystonia or paralysis $^{33,48}$.

Electroconvulsive stimulus. Detection of such non-seizuring events extends the range of epilepsy modeling in Drosophila and has benefited most from electrophysiological readouts ${ }^{30}$. Hyperexcitation in the central nervous system was induced through short electroconvulsive electric pulses lasting 0.1 to 0.5 milliseconds up to 3 second pulses ${ }^{49-51}$. Electric stimulation at larval stages allows investigation of adult-lethal seizure alleles in Drosophila such as slamdance ( $s d a)$, as it induces characteristic tremors in mutants that are visible in the high-contrast mouth hooks that can be seen in the otherwise translucent body ${ }^{49-51}$. The paradigms detailed in this and the previous two sections elicit heightened brain activity from where the giant fiber system plays an important role conveying stereotypic, seizure-like motor responses to the motor system, with the interesting exception of flight muscle ${ }^{49}$. This commonality suggests a degree of convergence in generating epilepsy-associated behavior patterns.

Genetic stimulus. Mutants in the para locus, such as the para $^{\text {bss }}$ hypermorph allele as well as knockdown alleles (as discussed in 'Tissue-specific genetic screening' below), have been thoroughly investigated for seizure-like behavior ${ }^{52}$. The alpha subunit of voltage-gated sodium channels Para mediates neuronal action potentials. The human orthologs $S C N 8 A, S C N 2 A$, and $S C N 1 A$ are strongly associated with pathogenic epilepsy phenotypes and carry several of the most frequent alleles associated with epilepsy ${ }^{53-55}$. Drosophila carrying the para $^{\text {bss }}$ mutation are sensitized to induced seizure-like attacks, notably even through optogenetic stimuli ${ }^{31,56} \cdot$ para $^{\text {bss }}$ mutants have also received attention for the identification of genetic interactors that suppress seizuring, among them gilgamesh (gish), which encodes a casein kinase 1 that is highly conserved in humans ${ }^{57}$. Genetic seizure modifier genes and downstream interacting genes are efficiently identified in Drosophila. An alternative case of predisposition for seizure-like behavior is the metabolic epilepsy model for PNPO deficiency (OMIM \#610090). Induction through a sugar-only diet in mutants of the fly gene sugarlethal ( $\mathrm{sgll}$ ), the orthologue of $P N P O$, elicited seizures without additional acute stimuli ${ }^{58}$.

Some bang-sensitive alleles are temperature sensitive, with shibire $^{t s}\left(s h i^{t s}\right)$ the most prominent example. shi encodes a dynamin and one of its human orthologs, DNM1, is linked to an early infantile epileptic encephalopathy (OMIM \#616346). These alleles produce proteins that lose function at conditions warmer than room temperature. Dynamin's functional relevance for epilepsy modeling was demonstrated by suppressing the seizure-like phenotypes of the well-known bang-sensitive genes para, easily shocked (eas), and sda through heat activation of the $s h i^{t s}$ allele $^{59}$. A further genetic rescue is the suppression of seizures in the TBC1D24 epilepsy and DOORS Syndrome (OMIM \#220500) ortholog skywalker (sky), which was mediated by the shi effector Synaptojanin $(\text { Synj })^{34}$.

Circadian rhythm. An environmental stimulus is required to induce seizure-like behavior in Drosophila carrying genetic mutations, with rare exceptions such as the prickle mutant $p k_{s p l}$ or the zydeco mutant $z y d^{l}$ when coupled with one out of several repo $>$ dStim knockdown lines ${ }^{60,61}$. One potential way to observe behavioral changes without triggering an acute response is to monitor sleep or activity patterns, and mutants that have seizure-like phenotypes often also have abnormal sleep. For example, shorter or more fragmented sleep periods were observed in the uncoordinated mutant Shaker $(S h)^{62}$, which is homologous to the epilepsy gene KCNA2 (OMIM \#616366), and for $s k y^{34}$. Several other well-studied bang sensitivity alleles are also sleep defective, including those affecting the epilepsy gene orthologs $I_{h}$ channel $(I h)$, para, and $s h i$, as well as two direct interactors of $S h$ potassium channels, quiver (qvr), and Shaker cognate $b(\text { Shab })^{63,64}$. This link between sleep abnormalities and seizures requires further investigation in humans and in animal models to better understand its applicability in clinical epilepsy research.

\section{Model-based steps towards effective epilepsy treatment}

The identification of over 100 rare genetic epilepsies suggests a broad range of disease mechanisms, such as synaptic transmission defects, channelopathies, and transcriptional, metabolic, and transport defects ${ }^{3,65-67}$. Despite this progress, most underlying mechanisms leading to epileptic diseases remain to be elucidated ${ }^{4}$. Systematic classification of causative genes is currently based on phenotypic patient descriptions. Genetic trends in the age of onset were determined through phenotypic distinction of 12 different groups, while at the same time a major overlap of the genotype-phenotype spectrum became apparent ${ }^{48}$. Mutations in genes coding for ion channel subunits underlie a high number of patient cases among hereditary epilepsies $^{68}$. An example are causative variants in SCN1A which are the most frequent cause of Dravet syndrome: more than $80 \%$ of patients carry variants of this ion channel subunit and are in general highly resistant to treatment ${ }^{69}$. 
To identify potential new treatments for Dravet syndrome and further drug-resistant conditions effectively, a high-throughput in vivo model can reveal brain-specific genetic interactors involved in epilepsy. Screens for suppressors of seizure-inducing alleles can reveal novel drug targets and point to related functional pathways. Previous large screens have identified genetic suppressors of seizure-like phenotypes. Alleles disrupting neuronal communication were also identified in non-ion channel genes, e.g. eas mutant seizure-like behavior or sky/TBC1D24 and synj/SYNJ1. In fact, the link in Drosophila between synj and epilepsy was found before human patient variants in SYNJ1-causing untreatable epilepsy had been identified in-72 $^{70}$ Beyond screening for phenotypical resemblance to seizures, suppressor screens, for instance in the genetic background of para ${ }^{b s s}$ mutant animals, determined genetic interactors of epilepsyassociated genes ${ }^{31,57}$. Suppressors have been identified in both unbiased and selective genetic screens, e.g. for sky/TBC1D24 $4^{34,71,73}$.

A large inhibitory RNA (RNAi)-based screen for behavioral phenotypes resulting from gene inactivation in glial cells has identified a number of bang-sensitive mutants, which are orthologs of human epilepsy-associated genes with roles in glial and, interestingly, glia-neuron interactions ${ }^{16,74,75}$.

In addition to mutant and knockdown models, the Drosophila community has developed 192 genetically inbred, or isogenized, lines known as the Drosophila melanogaster Genetic Reference Panel (DGRP), which enable the connection of epilepsyassociated phenotypes with multiple endogenous genetic loci, potentially leading to the discovery of new genetic modifiers ${ }^{76}$.

\section{Tissue-specific genetic screening}

Comprehensive libraries of transgenic lines are facilitating epilepsy and further genetic screens, among them very prominent collections of RNAi lines covering 91\% of Drosophila protein-coding genes ${ }^{77}$. These genetic libraries by the Vienna Drosophila Resource Center and the Transgenic RNAi Project at Harvard Medical School have the advantage of tissue-specific knockdown, whereas knockout lines, such as the MiMIC insertions which introduce insertion cassettes, often constitutively abrogate gene expression ${ }^{78,79}$. The RNAi-based screens are as versatile as the promotor lines combined with transcript knockdown, yet their effect strength has been found to vary and should be assessed independently from the phenotype ${ }^{80}$. Another 10,000 fly lines enabling knockdown in different neuronal and glial subsets have been generated in the Fly Light project ${ }^{81}$. Similar resources that take advantage of the CRISPR-Cas9 gene targeting system are under development (see Box 1).

Box 1. CRISPR-Cas9-based knockouts in screening

Inhibitory RNA (RNAi) knockdowns, while highly useful, are variable in the degree to which they inactivate the target gene. Libraries of fly stocks that express Cas9 and UAS-driven short-guide RNA elements will enable tissue-specific complete knockouts of any targeted gene ${ }^{82}$. These libraries will be a valuable alternative to the RNAi-based resources that are presently in broad use.

\section{Drug screens utilizing Drosophila}

The development of epilepsy treatments in animal models focuses on seizure-like readouts that can be suppressed through genetic interaction or application of pharmacological compounds ${ }^{83,84}$. Akin to genetic interactor screens, the interplay of seizure phenotypes with pharmacological inhibitors has been investigated, based on both known ASD as well as on novel substances. Picrotoxin-induced seizuring or genetic models such as eas flies served as screening models ${ }^{33,49,52,85}$. Testing known ASDs discovered responsiveness to pharmacological inhibitors such as phenytoin and nifedipine, but also to gabapentin, compounds that are effective against severe seizure pathologies $^{84,85}$. Just as in human epilepsies, screens found no single drug compound which could effectively suppress the many different underlying genetic changes in Drosophila ${ }^{11}$.

One potential limitation of focusing on seizure-like behavior readouts in the fly model is the omission of the wider phenotypic spectrum in epileptic encephalopathies, regarding both the method of treatment and its timing ${ }^{86,87}$. ID and autism spectrum disorders are examples of strongly co-occurring pathologies which are beginning to be integrated into current epilepsy and neurodevelopmental disease models in small animal models or in drug trials ${ }^{12,88-90}$.

\section{Future perspectives in drug screening}

Patients with drug-resistant epilepsy have a restricted quality of life and higher mortality, and the drug resistance may have cognitive and psychosocial consequences ${ }^{11}$. ASD alternatives are surgical intervention, neurostimulation, ketogenic diet, and lifestyle adjustment. Recent clinical studies suggested cannabidiol-based treatment as a therapeutic intervention in drug-resistant therapies and successful seizure suppressors in a Drosophila model ${ }^{91,92}$. Despite the enormous amount of research and the increasing number of available ASDs, there still remain epileptic patients who cannot be treated ${ }^{11}$.

\section{Unraveling epilepsies from two ends: patient variants or functional pathways}

The number of epilepsy-associated genes was expanded drastically when a whole-exome study of more than 17,000 individuals detected vast numbers of ultra-rare variants ${ }^{4}$. The large number of underlying genes combined with the small patient groups affected by individual variants require inexpensive and rapid methodologies to test anti-seizure measures. As discussed above, while stem cell-based methods potentially reveal precision medicine solutions, at the current moment Drosophila genetic screening offers rapid and economical insight into the genetic function and interactome of conserved genetic variants.

In a complementary direction, unbiased study of molecular pathways and genetic interactions connects known genes with each other as well as with new genes or unexpected causative variants in epilepsy. For example, $m t d / O X R 1$ and $s k y / T B C 1 D 24$ variants cause epilepsies that were found to be linked to reactive oxygen species levels and modified by anti-oxidants at the 
level of neurons as well as the entire brain, based on humanized Drosophila transgenic models in which the cDNA of patient variant OXR1 or TBC1D24 was expressed in the brain ${ }^{45,48}$. Humanization of the most frequent genetic cause underlying Dravet syndrome, point mutations in SCN1A, have enabled detailed studies of the effect conveyed by many of the mutations on protein function ${ }^{93}$. By understanding the mechanistic and functional connections between epilepsy-associated genes, a step from many unconnected single disorders to functional networks becomes more tangible. A third way to assess in which wider gene networks these single factors are functionally required is based on systems biology, specifically on brain transcriptomics ${ }^{94,95}$. Computational approaches have the potential to connect mouse and human in vitro data with Drosophila epilepsy in vivo models to obtain integrated conserved functional networks. This approach will hold validity across a range of disorders affecting the central nervous system ${ }^{7,8}$.

\section{Future perspective}

Epilepsy patient genetics provide unprecedented insights into common and more rare epilepsy conditions, many resistant to current treatment forms. Beyond their clinical phenotype, a shared genetic basis has been revealed that allows the investigation of converging genetic disease mechanisms ${ }^{96}$. Based on epilepsy genes identified by the International League Against Epilepsy (ILAE), previous computational approaches have been validated in cellular and mouse models, leading to a proposed mechanism of valproic acid function in SCN1A patient cases and to pre-clinical confirmation of Csf1r inhibitors as novel ASD candidates ${ }^{94,95}$. With the advent of whole-brain single-cell transcriptome datasets, recent developments have enabled the inference of connections between the orthologs of causative monogenic epilepsy factors at unprecedented resolution and will in the future support models of epilepsy gene networks ${ }^{97,98}$.

Grouping disease genes based on inferred genetic interactions and confirming candidate networks in efficient animal screens could become a valuable additional tool for expanding drug classifications of pre-clinical epilepsy models, associating epilepsies on their responsiveness to treatment as a new criterion. Functional connections and 'epilepsy gene networks' could guide genetic and pharmacological screens and ultimately future treatment strategies.
1. Heyne $\mathrm{HO}$, Singh $\mathrm{T}$, Stamberger $\mathrm{H}$, et al.: De novo variants in neurodevelopmental disorders with epilepsy. Nat Genet. 2018; 50(7): 1048-53. PubMed Abstract | Publisher Full Text | Faculty Opinions Recommendation

2. International League Against Epilepsy Consortium on Complex Epilepsies: Genetic determinants of common epilepsies: a meta-analysis of genome-wide association studies. Lancet Neurol. 2014; 13(9): 893-903. PubMed Abstract | Publisher Full Text | Free Full Text

3. McTague A, Howell KB, Cross JH, et al.: The genetic landscape of the epileptic encephalopathies of infancy and childhood. Lancet Neurol. 2016; 15(3): 304-16. PubMed Abstract | Publisher Full Text

4. Epi25 Collaborative: Ultra-Rare Genetic Variation in the Epilepsies: A Whole-Exome Sequencing Study of 17,606 Individuals. Am J Hum Genet. 2019; 105(2): 267-82.

PubMed Abstract | Publisher Full Text | Free Full Text |

Faculty Opinions Recommendation

5. Mohammadi NA, Freude K, Haukedal $\mathrm{H}$, et al:: Human induced pluripotent cells in personalized treatment of monogenic epilepsies. $J$ Transl Genet Genomics. 2020; 4: 238-50.

Publisher Full Text

6. Yamamoto S, Jaiswal M, Charng WL, et al.: A drosophila genetic resource of mutants to study mechanisms underlying human genetic diseases. Cell. 2014; 159(1): 200-14.

PubMed Abstract | Publisher Full Text | Free Full Text |

Faculty Opinions Recommendation

7. Pandey UB, Nichols CD: Human disease models in Drosophila melanogaster and the role of the fly in therapeutic drug discovery. Pharmacol Rev. 2011; 63(2): 411-36.

PubMed Abstract | Publisher Full Text | Free Full Text

8. Ugur B, Chen K, Bellen HJ: Drosophila tools and assays for the study of human diseases. Dis Model Mech. 2016; 9(3): 235-44. PubMed Abstract | Publisher Full Text | Free Full Text

9. Bateman JR, Lee AM, Wu CT: Site-specific transformation of Drosophila via phiC31 integrase-mediated cassette exchange. Genetics. 2006; 173(2): 769-77. PubMed Abstract | Publisher Full Text | Free Full Text

10. Kwan P, Brodie MJ: Early identification of refractory epilepsy. N Engl J Med. 2000; 342(5): 314-9. PubMed Abstract | Publisher Full Text
11. Tang F, Hartz AMS, Bauer B: Drug-Resistant Epilepsy: Multiple Hypotheses, Few Answers. Front Neurol. 2017; 8: 301. PubMed Abstract | Publisher Full Text | Free Full Text

12. French JA, Perucca E: Time to Start Calling Things by Their Own Names? The Case for Antiseizure Medicines. Epilepsy Curr. 2020; 20(2): 69-72. PubMed Abstract | Publisher Full Text | Free Full Text | Faculty Opinions Recommendation

13. Geissmann Q, Garcia Rodriguez L, Beckwith EJ, et al:: Ethoscopes: An open platform for high-throughput ethomics. PLOS Biol. 2017; 15(10): e2003026. PubMed Abstract | Publisher Full Text | Free Full Text

14. Howlett IC, Tanouye MA: Neurocircuit assays for seizures in epilepsy mutants of Drosophila. J Vis Exp. 2009; (26): 1121.

PubMed Abstract | Publisher Full Text | Free Full Text

15. Stone B, Burke B, Pathakamuri J, et al.: A low-cost method for analyzing seizure-like activity and movement in Drosophila. J Vis Exp. 2014; (84): e51460. PubMed Abstract | Publisher Full Text | Free Full Text

16. Otto N, Marelja Z, Schoofs A, et al:: The sulfite oxidase Shopper controls neuronal activity by regulating glutamate homeostasis in Drosophila ensheathing glia. Nat Commun. 2018; 9(1): 3514. PubMed Abstract | Publisher Full Text | Free Full Text

17. Triphan T, Nern A, Roberts SF, et al:: A screen for constituents of motor control and decision making in Drosophila reveals visual distance-estimation neurons. Sci Rep. 2016; 6: 27000.

PubMed Abstract | Publisher Full Text | Free Full Text

18. Robie AA, Hirokawa J, Edwards AW, et al.: Mapping the Neural Substrates of Behavior. Cell. 2017; 170(2): 393-406.e28. PubMed Abstract | Publisher Full Text

19. Berman GJ, Bialek W, Shaevitz JW: Predictability and hierarchy in Drosophila behavior. Proc Natl Acad Sci U S A. 2016; 113(42): 11943-8. PubMed Abstract | Publisher Full Text | Free Full Text

20. Song J, Tanouye MA: From bench to drug: human seizure modeling using Drosophila. Prog Neurobiol. 2008; 84(2): 182-91. PubMed Abstract | Publisher Full Text | Free Full Text

21. Burg MG, Wu CF: Mechanical and temperature stressor-induced seizure-andparalysis behaviors in Drosophila bang-sensitive mutants. J Neurogenet. 2012; 26(2): 189-97. PubMed Abstract | Publisher Full Text | Free Full Text

22. Reiter LT, Potocki L, Chien S, et al.: A systematic analysis of human 
disease-associated gene sequences in Drosophila melanogaster. Genome Res. 2001; 11(6): 1114-25.

PubMed Abstract | Publisher Full Text | Free Full Text

23. DJan M, O'Hara BF, Franken P. Recent advances in understanding the genetics of sleep [version 1; peer review: 3 approved]. F1000Res. 2020; 9 F1000 Faculty Rev-214. PubMed Abstract | Publisher Full Text | Free Full Text | Faculty Opinions Recommendation

24. Hope KA, Flatten D, Cavitch P, et al:: The Drosophila Gene Sulfateless Modulates Autism-Like Behaviors. Front Genet. 2019; 10: 574 PubMed Abstract | Publisher Full Text | Free Full Text

25. Hebbar M, Mefford HC: Recent advances in epilepsy genomics and genetic testing [version 1; peer review: 2 approved]. F1000Res. 2020; 9. PubMed Abstract | Publisher Full Text | Free Full Text | Faculty Opinions Recommendation

26. Takai A, Yamaguchi M, Yoshida H, et al.: Investigating Developmental and Epileptic Encephalopathy Using Drosophila melanogaster. Int J Mol Sci. 2020; 21(7): 6442 .

PubMed Abstract | Publisher Full Text | Free Full Text |

Faculty Opinions Recommendation

27. Rusan ZM, Kingsford OA, Tanouye MA: Modeling glial contributions to seizures and epileptogenesis: cation-chloride cotransporters in Drosophila melanogaster. PLoS One. 2014; 9(6): e101117.

PubMed Abstract | Publisher Full Text | Free Full Text

28. HopeKA,LeDouxMS,ReiterLT:GlialoverexpressionofDube3acausesseizuresandsynaptic impairments in Drosophila concomitant with down regulation of the $\mathrm{Na}^{+} / \mathrm{K}^{+}$ pump ATPa. Neurobiol Dis. 2017; 108: 238-48.

PubMed Abstract | Publisher Full Text | Free Full Text

29. Benzer S: From the Gene to Behavior. JAMA. 1971; 218(7): 1015-22. PubMed Abstract | Publisher Full Text

30. Kuebler D, Tanouye MA: Modifications of seizure susceptibility in Drosophila. J Neurophysiol. 2000; 83(2): 998-1009. PubMed Abstract | Publisher Full Text

31. Parker L, Padilla M, Du Y, et al:: Drosophila as a model for epilepsy: bss is a gain-of-function mutation in the para sodium channel gene that leads to seizures. Genetics. 2011; 187(2): 523-34.

PubMed Abstract | Publisher Full Text | Free Full Text

32. Helbig I, Heinzen EL, Mefford HC: Primer Part 1-The building blocks of epilepsy genetics. Epilepsia. 2016; 57(6): 861-8.

PubMed Abstract | Publisher Full Text

33. Leal SM, Neckameyer WS: Pharmacological evidence for GABAergic regulation of specific behaviors in Drosophila melanogaster. J Neurobiol. 2002; 50(3): 245-61.

PubMed Abstract | Publisher Full Text

34. Fischer B, Lüthy K, Paesmans J, et al.: Skywalker-TBC1D24 has a lipid-binding pocket mutated in epilepsy and required for synaptic function. Nat Struct Mol Biol. 2016; 23(11): 965-73. PubMed Abstract | Publisher Full Text

35. Weiss S, Melom JE, Ormerod KG, et al.: Glial $\mathrm{Ca}^{2+}$ signaling links endocytosis to $\mathrm{K}^{+}$buffering around neuronal somas to regulate excitability. eLife. 2019; 8: e44186.

PubMed Abstract | Publisher Full Text | Free Full Text |

Faculty Opinions Recommendation

36. Praschberger R, Lowe SA, Malintan NT, et al:: Mutations in Membrin/GOSR2 Reveal Stringent Secretory Pathway Demands of Dendritic Growth and Synaptic Integrity. Cell Rep. 2017; 21(1): 97-109. PubMed Abstract | Publisher Full Text | Free Full Text

37. Crompton D, Todman M, Wilkin M, et al.: Essential and neural transcripts from the Drosophila shaking- $B$ locus are differentially expressed in the embryonic mesoderm and pupal nervous system. Dev Biol. 1995; 170(1): 142-58. PubMed Abstract | Publisher Full Text

38. Phelan $\mathrm{P}$, Nakagawa $\mathrm{M}$, Wilkin $\mathrm{MB}$, et al.: Mutations in shaking-B prevent electrical synapse formation in the Drosophila giant fiber system. $J$ Neurosci. 1996; 16(3): 1101-13.

PubMed Abstract | Publisher Full Text | Free Full Tex

39. Zhang $Y Q$, Roote J, Brogna $S$, et al:: stress sensitive $B$ encodes an adenine nucleotide translocase in Drosophila melanogaster. Genetics. 1999; 153(2): 891-903.

PubMed Abstract | Free Full Text

40. Moss GWJ, Marshall J, Morabito M, et al:: An evolutionarily conserved binding site for serine proteinase inhibitors in large conductance calcium-activated potassium channels. Biochemistry. 1996; 35(50): 16024-35. PubMed Abstract | Publisher Full Text

41. Titus SA, Warmke JW, Ganetzky B: The Drosophila erg $\mathbf{K}^{+}$channel polypeptide is encoded by the seizure locus. J Neurosci. 1997; 17(3): 875-81. PubMed Abstract | Publisher Full Text | Free Full Text

42. Wang $X$, Reynolds ER, Déak $P$, et al.: The seizure locus encodes the Drosophila homolog of the HERG potassium channel. J Neurosci. 1997; 17(3): 882-90. PubMed Abstract | Publisher Full Text | Free Full Text

43. Pavlidis P, Ramaswami M, Tanouye MA: The Drosophila easily shocked gene: a mutation in a phospholipid synthetic pathway causes seizure, neuronal failure, and paralysis. Cell. 1994; 79(1): 23-33.

PubMed Abstract | Publisher Full Text

44. Salkoff L, Wyman R: Genetic modification of potassium channels in Drosophila Shaker mutants. Nature. 1981; 293(5829): 228-30. PubMed Abstract | Publisher Full Text

45. W Wang J, Rousseau J, Kim E, et al.: Loss of Oxidation Resistance 1, OXR1, Is Associated with an Autosomal-Recessive Neurological Disease with Cerebellar Atrophy and Lysosomal Dysfunction. Am J Hum Genet. 2019; 105(6): 1237-53.

PubMed Abstract | Publisher Full Text | Free Full Text |

Faculty Opinions Recommendation

46. Mylvaganam S, Ramani M, Krawczyk M, et al:: Roles of gap junctions, connexins, and pannexins in epilepsy. Front Physiol. 2014; 5: 172. PubMed Abstract | Publisher Full Text | Free Full Text

47. Dean $\mathrm{D}$, Weinstein $\mathrm{H}$, Amin $\mathrm{S}$, et al.: Extending julius seizure, a bang-sensitive gene, as a model for studying epileptogenesis: Cold shock, and a new insertional mutation. Fly (Austin). 2018; 12(1): 55-61.

PubMed Abstract | Publisher Full Text | Free Full Text

48. Lüthy K, Mei D, Fischer B, et al.: TBC1D24-TLDc-related epilepsy exerciseinduced dystonia: rescue by antioxidants in a disease model. Brain. 2019; 142(8): 2319-35.

PubMed Abstract | Publisher Full Text

49. Lee J, Wu CF: Electroconvulsive seizure behavior in Drosophila: analysis of the physiological repertoire underlying a stereotyped action pattern in bangsensitive mutants. J Neurosci. 2002; 22(24): 11065-79. PubMed Abstract | Publisher Full Text | Free Full Text

50. Marley $\mathrm{R}$, Baines RA: Increased persistent $\mathrm{Na}^{+}$current contributes to seizure in the slamdance bang-sensitive Drosophila mutant. J Neurophysiol. 2011; 106(1): 18-29.

PubMed Abstract | Publisher Full Text | Free Full Text

51. Zhang $\mathrm{H}$, Tan J, Reynolds $\mathrm{E}$, et al:: The Drosophila slamdance gene: a mutation in an aminopeptidase can cause seizure, paralysis and neuronal failure. Genetics. 2002; 162(3): 1283-99.

PubMed Abstract | Free Full Text

52. Lin WH, Giachello CNG, Baines RA: Seizure control through genetic and pharmacological manipulation of Pumilio in Drosophila: a key component of neuronal homeostasis. Dis Model Mech. 2017; 10(2): 141-50. PubMed Abstract | Publisher Full Text | Free Full Text

53. Claes L, Del-Favero J, Ceulemans B, et al: De novo mutations in the sodiumchannel gene SCN1A cause severe myoclonic epilepsy of infancy. Am J Hum Genet. 2001; 68(6): 1327-32.

PubMed Abstract | Publisher Full Text | Free Full Text

54. Depienne C, Trouillard O, Saint-Martin C, et al.: Spectrum of SCN1A gene mutations associated with Dravet syndrome: analysis of $\mathbf{3 3 3}$ patients. $J$ Med Genet. 2009; 46(3): 183-91.

PubMed Abstract | Publisher Full Text

55. Meisler MH, Kearney JA: Sodium channel mutations in epilepsy and other neurological disorders. J Clin Invest. 2005; 115(8): 2010-7. PubMed Abstract | Publisher Full Text | Free Full Text

56. Saras A, Wu VV, Brawer HJ, et al:: Investigation of Seizure-Susceptibility in a Drosophila melanogaster Model of Human Epilepsy with Optogenetic Stimulation. Genetics. 2017; 206(4): 1739-46.

PubMed Abstract | Publisher Full Text | Free Full Text

57. Howlett IC, Rusan ZM, Parker L, et al:: Drosophila as a model for intractable epilepsy: gilgamesh suppresses seizures in para ${ }^{\text {bss } 1}$ heterozygote flies. G3 (Bethesda). 2013; 3(8): 1399-407.

PubMed Abstract | Publisher Full Text | Free Full Text

58. Chi W, lyengar ASR, Albersen M, et al:: Pyridox (am) ine 5'-phosphate oxidase deficiency induces seizures in Drosophila melanogaster. Hum Mol Genet. 2019 28(18): 3126-36.

PubMed Abstract | Publisher Full Text | Free Full Text

59. Kroll JR, Wong KG, Siddiqui FM, et al.: Disruption of Endocytosis with the Dynamin Mutant shibire ${ }^{\text {ts } 1}$ Suppresses Seizures in Drosophila. Genetics. 2015 201(3): 1087-102.

PubMed Abstract | Publisher Full Text | Free Full Text

60. Weiss S, Clamon LC, Manoim JE, et al.: Disruption of Glial $\mathrm{Ca}^{2+}$ Oscillations at the Drosophila Blood-Brain Barrier Predisposes to Seizure-Like Behavior. bioRxiv. 2020; 2020.09.16.285841.

Publisher Full Text

61. Ehaideb SN, Wignall EA, Kasuya J, et al.: Mutation of orthologous prickle genes causes a similar epilepsy syndrome in flies and humans. Ann Clin Transl Neurol. 2016; 3(9): 695-707.

PubMed Abstract | Publisher Full Text | Free Full Text

62. Cirelli C, Bushey D, Hill S, et al.: Reduced sleep in Drosophila Shaker mutants. Nature. 2005; 434(7037): 1087-92.

PubMed Abstract | Publisher Full Text | Faculty Opinions Recommendation

63. Lucey BP, Leahy A, Rosas R, et al:: A new model to study sleep deprivationinduced seizure. Sleep. 2015; 38(5): 777-85.

PubMed Abstract | Publisher Full Text | Free Full Text

64. Andretic R, Shaw PJ: Essentials of sleep recordings in Drosophila: moving beyond sleep time. Meth Enzymol. 2005; 393: 759-72.

PubMed Abstract | Publisher Full Text 
65. Wolking S, May P, Mei D, et al.: Clinical spectrum of STX1B-related epileptic disorders. Neurology. 2019; 92(11): e1238-e1249.

PubMed Abstract | Publisher Full Text | Free Full Text |

Faculty Opinions Recommendation

66. Balestrini S, Milh M, Castiglioni C, et al.: TBC1D24 genotype-phenotype correlation: Epilepsies and other neurologic features. Neurology. 2016; 87(1): $77-85$.

PubMed Abstract | Publisher Full Text | Free Full Text

67. Krey I, Krois-Neudenberger J, Hentschel J, et al:: Genotype-phenotype correlation on $\mathbf{4 5}$ individuals with West syndrome. Eur J Paediatr Neurol. 2020 25: 134-8.

PubMed Abstract | Publisher Full Text

68. Orsini A, Zara F, Striano P: Recent advances in epilepsy genetics. Neurosci Lett. 2018; 667: 4-9.

PubMed Abstract | Publisher Full Text | Faculty Opinions Recommendation

69. Marini C, Scheffer IE, Nabbout R, et al.: The genetics of Dravet syndrome. Epilepsia. 2011; 52 Suppl 2: 24-9.

PubMed Abstract | Publisher Full Text

70. Verstreken $\mathrm{P}, \mathrm{Koh}$ TW, Schulze KL, et al:: Synaptojanin is recruited by endophilin to promote synaptic vesicle uncoating. Neuron. 2003; 40(4): 733-48. PubMed Abstract | Publisher Full Text

71. Uytterhoeven V, Kuenen S, Kasprowicz J, et al.: Loss of skywalker reveals synaptic endosomes as sorting stations for synaptic vesicle proteins. Cell. 2011; 145(1): 117-32.

PubMed Abstract | Publisher Full Text

72. Song J, Hu J, Tanouye M: Seizure suppression by top1 mutations in

Drosophila. J Neurosci. 2007; 27(11): 2927-37.

PubMed Abstract | Publisher Full Text | Free Full Text

73. Fernandes AC, Uytterhoeven V, Kuenen S, et al:: Reduced synaptic vesicle protein degradation at lysosomes curbs TBC1D24/sky-induced neurodegeneration. J Cell Biol. 2014; 207(4): 453-62. PubMed Abstract | Publisher Full Text | Free Full Text

74. Kottmeier R, Bittern J, Schoofs A, et al.: Wrapping glia regulates neuronal signaling speed and precision in the peripheral nervous system of Drosophila. Nat Commun. 2020; 11(1): 4491.

PubMed Abstract | Publisher Full Text | Free Full Text

75. Bittern J, Pogodalla N, Ohm H, et al.: Neuron-glia interaction in the Drosophila nervous system. Dev Neurobiol. 2020. PubMed Abstract | Publisher Full Text | Faculty Opinions Recommendation

76. Mackay TFC, Richards S, Stone EA, et al.: The Drosophila melanogaster Genetic Reference Panel. Nature. 2012; 482(7384): 173-8.

PubMed Abstract | Publisher Full Text | Free Full Text |

Faculty Opinions Recommendation

77. Dietzl G, Chen D, Schnorrer F, et al:: A genome-wide transgenic RNAi library for conditional gene inactivation in Drosophila. Nature. 2007; 448(7150): 151-6. PubMed Abstract | Publisher Full Text | Faculty Opinions Recommendation

78. Venken KJT, Schulze KL, Haelterman NA, et al.: MiMIC: a highly versatile transposon insertion resource for engineering Drosophila melanogaster genes. Nat Methods. 2011; 8(9): 737-43.

PubMed Abstract | Publisher Full Text | Free Full Text

79. Perkins LA, Holderbaum L, Tao R, et al:: The Transgenic RNAi Project at Harvard Medical School: Resources and Validation. Genetics. 2015; 201(3): 843-52. PubMed Abstract | Publisher Full Text | Free Full Text

80. Kaya-Çopur A, Schnorrer F: A Guide to Genome-Wide In Vivo RNAi Applications in Drosophila. Methods Mol Biol. 2016; 1478: 117-43.

PubMed Abstract | Publisher Full Text

81. Jenett A, Rubin GM, Ngo TTB, et al:: A GAL4-driver line resource for Drosophila neurobiology. Cell Rep. 2012; 2(4): 991-1001. PubMed Abstract | Publisher Full Text | Free Full Text

82. Ewen-Campen B, Mohr SE, Hu Y, et al.: Accessing the Phenotype Gap: Enabling Systematic Investigation of Paralog Functional Complexity with CRISPR. Dev Cell. 2017; 43(1): 6-9.

PubMed Abstract | Publisher Full Tex
83. Ganetzky B, Wu CF: Indirect Suppression Involving Behavioral Mutants with Altered Nerve Excitability in DROSOPHILA MELANOGASTER. Genetics. 1982; 100(4): 597-614. PubMed Abstract | Free Full Text

84. Reynolds ER, Stauffer EA, Feeney L, et al:: Treatment with the antiepileptic drugs phenytoin and gabapentin ameliorates seizure and paralysis of Drosophila bang-sensitive mutants. J Neurobiol. 2004; 58(4): 503-13. PubMed Abstract | Publisher Full Text

85. Stilwell GE, Saraswati S, Littleton JT, et al.: Development of a Drosophila seizure model for in vivo high-throughput drug screening. Eur J Neurosci. 2006; 24(8): 2211-22.

PubMed Abstract | Publisher Full Text

86. Grant SGN: Synaptopathies: diseases of the synaptome. Curr Opin Neurobiol. 2012; 22(3): 522-9.

PubMed Abstract | Publisher Full Text

87. Lepeta K, Lourenco MV, Schweitzer BC, et al:: Synaptopathies: synaptic dysfunction in neurological disorders - A review from students to students. J Neurochem. 2016; 138(6): 785-805.

PubMed Abstract | Publisher Full Text | Free Full Text

88. Löscher W, Potschka H, Sisodiya SM, et al.: Drug Resistance in Epilepsy: Clinical Impact, Potential Mechanisms, and New Innovative Treatment Options. Pharmacol Rev. 2020; 72(3): 606-38. PubMed Abstract | Publisher Full Text | Free Full Text Faculty Opinions Recommendation

89. Moscato EH, Dubowy C, Walker JA, et al:: Social Behavioral Deficits with Loss of Neurofibromin Emerge from Peripheral Chemosensory Neuron Dysfunction. Cell Rep. 2020; 32(1): 107856.

PubMed Abstract | Publisher Full Text | Free Full Text | Faculty Opinions Recommendation

90. Stessman HAF, Xiong B, Coe BP, et al:: Targeted sequencing identifies $\mathbf{9 1}$ neurodevelopmental-disorder risk genes with autism and developmentaldisability biases. Nat Genet. 2017; 49(4): 515-26. PubMed Abstract | Publisher Full Text | Free Full Tex

91. Devinsky O, Cross JH, Laux L, et al:: Trial of Cannabidiol for Drug-Resistant Seizures in the Dravet Syndrome. N Engl J Med. 2017; 376(21): 2011-20. PubMed Abstract | Publisher Full Text | Faculty Opinions Recommendation

92. Jacobs JA, Sehgal A: Anandamide Metabolites Protect against Seizures through the TRP Channel Water Witch in Drosophila melanogaster. Cell Rep. 2020; 31(9): 107710.

PubMed Abstract | Publisher Full Text | Faculty Opinions Recommendation

93. Schutte SS, Schutte RJ, Barragan EV, et al.: Model systems for studying cellular mechanisms of SCN1A-related epilepsy. J Neurophysiol. 2016; 115(4): 1755-66. PubMed Abstract | Publisher Full Text | Free Full Text

94. Delahaye-Duriez A, Srivastava P, Shkura K, et al.: Rare and common epilepsies converge on a shared gene regulatory network providing opportunities for novel antiepileptic drug discovery. Genome Biol. 2016; 17(1): 245.

PubMed Abstract | Publisher Full Text | Free Full Text | Faculty Opinions Recommendation

95. Srivastava PK, van Eyll J, Godard P, et al:: A systems-level framework for drug discovery identifies Csf1R as an anti-epileptic drug target. Nat Commun. 2018; 9(1): 3561.

PubMed Abstract | Publisher Full Text | Free Full Text | Faculty Opinions Recommendation

96. Striano P, Zara F: Epilepsy: Common and rare epilepsies share genetic determinants. Nat Rev Neurol. 2017; 13(4): 200-1. PubMed Abstract | Publisher Full Text

97. Davie K, Janssens J, Koldere D, et al:: A Single-Cell Transcriptome Atlas of the Aging Drosophila Brain. Cell. 2018; 174(4): 982-998.e20. PubMed Abstract | Publisher Full Text | Free Full Text

98. Croset V Treiber CD, Waddell S: Cellular diversity in the Drosophila midbrain revealed by single-cell transcriptomics. eLife. 2018; 7: e34550. PubMed Abstract | Publisher Full Text | Free Full Text 